\title{
A Remedy for Historical Split Personalities: In Memory of Carlos S. Alvarado'
}

\author{
Andreas Sommer
}

One of the proudest moments in my career was when I received a request last year to review a funding proposal for Carlos's planned book with the preliminary title The Hidden and Fragmented Mind, 1880s-1900: The Society for Psychical Research. This was to be an elaboration on material he had published in the Journal of Trauma and Dissociation almost twenty years ago (Alvarado, 2002). As I was grateful to state in my report, together with earlier work by Carlos - such as an article in the journal Dissociation (Alvarado, 1989) - this essay had significantly shaped the direction of my own research on historical cross-links between modern psychology and psychical research from the very start.

The path of investigation followed by Carlos himself was first laid out in encyclopedic scope by psychiatrist Henri F. Ellenberger (1970), who demonstrated fundamental omissions and distortions in official chronologies of the modern mind sciences: Whereas psychologists and psychiatrists often seem conditioned to view the historical relation between their disciplines and the "occult" in simplistic terms of a victory of "science" over "superstition," Ellenberger was the first to show in great detail the indebtedness of modern concepts of the subconscious mind to traditions like mesmerism, spiritualism, and psychical research. Of course, not all of Ellenberger's work was specifically concerned with the "paranormal." One could even say he had only begun to scratch the surface in this regard, so there was still plenty of work left for Carlos and the few others who would follow him.

Carlos's name is familiar to anyone in the small community of parapsychological investigators today, but it is perhaps not widely known that his research has informed the work of several mainstream scholars. One of the first to draw on Carlos's findings was Harvard historian of science and medicine Anne Harrington (1987), in a major contribution to the history of the neurosciences. Carlos had only started warm-

1 Address correspondence to: Andreas Sommer, Ph. D., sommer@forbiddenhistories.com 
ing up at the time, so the material used by Harrington had not been even published yet. Six years later, Mark Micale (1993), a leading historian of psychiatry, included Carlos's published output in a bibliographical essay on important contributions to Ellenberger-style historical research.

Harrington's book was part of a growing body of sophisticated historical studies challenging Western obsessions with "brainhood" (Vidal, 2009) - the belief that anything worthwhile learning about human nature could be known by studying the brain. Although popularizers of mind-brain reductionism are fond of asserting this as an inevitable corollary of centuries of unbiased science, historians of neurosciences have shown such claims to rest on little more than cultural myths. Several proponents of brainhood have also maintained that open-minded scientific curiosity in reported psychic phenomena is inherently motivated by a wish to uphold beliefs in immaterial souls. Carlos's essays on French physiologist Charles Richet - several of which were compiled in his first book (Alvarado, 2019) - are therefore an important reminder of the actual metaphysical pluralism of parapsychological research: Richet, a Nobel Laureate in physiology and the doyen of psychical research in France, was in fact an outspoken proponent of the view that minds are reducible to brain processes. Yet, he still published empirical evidence for the occurrence of parapsychological phenomena.

Carlos's works on Richet, along with overviews of investigations and ideas by many other historical key authors writing in French, German, Italian, Spanish, and Portuguese, are a testament to his mastery of primary and secondary sources in languages not limited to English. When I guest-edited a special section with articles on psychical research for the journal Studies in History and Philosophy of the Biological and Biomedical Science, I was therefore grateful to have Carlos on board as a reviewer of an article about another research specialty of his: the Italian psychiatrist Enrico Morselli and his experiments with the medium Eusapia Palladino (Brancaccio, 2014).

Richet and Morselli might not be scientific household names today, but William James - a pioneer of experimental psychology in the USA - certainly is. Modern psychologists are bound to be surprised to learn that James published most of his empirical work in unorthodox periodicals, predominantly the Proceedings of the American Society for Psychical Research (ASPR). Thanks to Carlos, one of these texts by James, his 1886 report of the ASPR's research committee on mediumship, was republished in the journal History of Psychiatry, and Carlos wrote the introduction (Alvarado, 2016; for the wider context of James's psychical research see also Sommer, 2020).

Until about the 1990s, it was almost customary for James scholars to downplay if not completely bypass his psychical research, as something supposedly unrelated 
to his "real" scientific and philosophical work. The continuing denial that, for example, James considered English psychical researchers Edmund Gurney and F.W.H. Myers (the inventor of the word telepathy) his closest allies in experimental psychology (for evidence see Kelly et al., 2007, Sommer, 2013), has led to the construction of James as a historical "split personality" in the public understanding of psychology. It therefore seems that what Carlos once observed concerning the history of dissociation applies to the history of the mind sciences in general: "much of our current understanding of the history of dissociation has been itself 'dissociated' in the sense of becoming separated from aspects of its origins" (Alvarado, 2002, p. 28).

Science historians have long recognized that the very writing of history has been a powerful means to create artificial boundaries between legitimate sciences and certain stereotypical "pseudosciences." I was therefore happy to accept an invitation to edit a special issue of the Parapsychological Association's magazine Mindfield, whose articles explored strategies by which serious research on the paranormal has been kept out of the scientific mainstream. An important focus of contributions was on the marginalization of various research questions from within parapsychology itself and, as my last formal collaboration with Carlos, I invited him to write an article which he chose to specifically dedicate to this topic (Alvarado, 2020).

Carlos's output in mainstream academic journals was considerable, but the bulk of his works have been published in periodicals not usually read by orthodox scientists. By sharing his immense knowledge, Carlos wanted to help both conventional and heterodox scientists maintain a certain level of historical literacy - which I can assure you is no easy task, as scientists often seem to regard history a waste of time. That this is wrong was often shown by Carlos himself, for example in a historically informed chapter on the clinical status of out-of-body experiences in the first edition of the seminal Varieties of Anomalous Experience (Alvarado, 2000) and a joint article on related problems in the second edition (Cardeña \& Alvarado, 2014).

Let me say farewell to Carlos by coming back to his dissociation metaphor quoted above. I believe that what is true for individual therapeutic contexts broadly applies to a collective level as well: Suppressed vital aspects of our biographies, of who we are, typically come back to bite us unless we make a conscious effort to integrate them. Works like Varieties of Anomalous Experience have responded to an egregious practical and clinical consequence of this suppression as part and parcel of Western modernity: the long history of blanket diagnoses of certain exceptional experiences as intrinsically morbid and pathological. Historical illiteracy, especially if it is an expression of reluctance to face certain cultural realities, thus comes at a cost. By losing Carlos, we have been deprived of one of our richest remedies for it. 


\section{References}

Alvarado, C. S. (1989). Dissociation and state-specific psychophysiology during the nineteenth century. Dissociation, 2(3), 160-168.

Alvarado, C. S. (2000). Out-of-body experiences. In E. Cardeña, S. J. Lynn, \& S. Krippner (Eds.), Varieties of anomalous experience: Examining the scientific evidence (pp. 183-218). American Psychological Association.

Alvarado, C. S. (2002). Dissociation in Britain during the late nineteenth century: The Society for Psychical Research, 1882-1900. Journal of Trauma \& Dissociation, 3(2), 9-33.

Alvarado, C. S. (2016). Introduction to Classic Text No. 1-205: 'Report of the committee on mediumistic phenomena', by William James (1886). History of Psychiatry, 27(1), 85-91.

Alvarado, C. S. (2019). Charles Richet. A Nobel Prize winning scientist's exploration of psychic phenomena. White Crow Books.

Alvarado, C. S. (2020). Boundary-work within parapsychology. Mindfield, 12(2), 49-55.

Brancaccio, M. T. (2014). Enrico Morselli's Psychology of "spiritism": Psychiatry, psychology and psychical research in Italy around 1900. Studies in History and Philosophy of Biological and Biomedical Sciences, 48 (Part A), 75-84.

Cardeña, E., \& Alvarado, C. S. (2014). Anomalous self and identity experiences. In E. Cardeña, S. J. Lynn, \& S. Krippner (Eds.), Varieties of anomalous experience: Examining the scientific evidence (pp. 175-212). American Psychological Association.

Ellenberger, H. F. (1970). The discovery of the unconscious: The history and evolution of dynamic psychiatry. Basic.

Harrington, A. (1987). Medicine, mind, and the double brain. A study in nineteenth-century thought. Princeton University Press.

Kelly, E. F., Kelly, E. W., Crabtree, A., Gauld, A., Grosso, M., \& Greyson, B. (2007). Irreducible mind. Toward a psychology for the 21st century. Rowman \& Littlefield.

Micale, M. S. (1993). Bibliographical essay. In M. S. Micale (Ed.), Beyond the unconscious: Essays of Henri F. Ellenberger in the history of psychiatry (pp. 379-414). Princeton University Press.

Sommer, A. (2013). Crossing the boundaries of mind and body. Psychical research and the origins of modern psychology. (PhD thesis). University College London.

Sommer, A. (2020). James and psychical research in context. In A. Klein (Ed.), The Oxford handbook of William James. Oxford University Press. Doi: 10.1093/oxfordhb/9780199395699.013.37 (Epub ahead of print)

Vidal, F. (2009). Brainhood, anthropological figure of modernity. History of the Human Sciences, $22(1), 5-36$. 